\title{
SECONDARY STUDENTS' ATTITUDES TOWARDS LINGUISTIC DIVERSITY: AN INVESTIGATION ON INDIVIDUAL AND EDUCATIONAL ASPECTS IN ITALIAN SCHOOLS
}

\author{
Martina Bellinzona, Valentina Carbonara ${ }^{1}$
}

\section{INTRODUCTION}

In the last decade, the 'multilingual turn' (May, 2013), claimed by several scholars, has been challenging the view of language, blurring the boundaries between traditional labels like L1 and L2. However, this permeable concept of bi/multilingualism is still divergent from classroom reality. Apart from specific experiences (Cummins, Early, 2011; García, Kleyn, 2016; Duarte, Günther-van der Meij, 2018; Little, Kirwan, 2019; Carbonara, Scibetta, 2020a) the monolingual paradigm is predominant in mainstream education, as is a defective representation of those non-conforming speakers, namely, immigrant minorities.

As Lasagabaster stated (2015: 22) «attitudes towards languages are manifestly affected and motivated by the languages' presence and their role in education». Language attitudes influence language behaviours, self and hetero perceptions in identity constructions, instructional practices, and eventually micro and macro language policies. For this reason, investigating attitudes towards linguistic diversity could give some valuable insights into the conditions which might support the legitimization and the affirmation of an heteroglossic perspective in education. At the same time, rising awareness of the factors which can have a positive effect on attitudes could encourage educators and policymakers to carefully plan and design specific interventions and learning strategies with the purpose of sustaining an ecological multilingual stance among students.

This paper aims to explore secondary students' language attitudes and beliefs towards linguistic diversity and multilingualism in Italian school and in society. Specifically, we will address the following research questions:

1. What attitudes do Italian secondary students have towards linguistic diversity?

2. Which individual factors have the greatest impact and can be considered the main predictors of students' attitudes towards linguistic diversity?

3. Which features of the educational environment, including the informed adoption of specific approaches to multilingual education, predominantly influence students' attitudes towards linguistic diversity?

Firstly, we will outline the main research strands on language attitudes in order to provide a foundation for the present study, and we will include a brief overview of the Italian context, showing how educational approaches to multilingualism have been partially shaped by European language policy and international experiences. Subsequently, we will describe the methodology, the research procedures and the participants' characteristics in this study. Finally, we will illustrate and discuss the main results,

\footnotetext{
${ }^{1}$ Università per Stranieri di Siena. Martina Bellinzona wrote Paragraphs 2, 4, 5 and 6.2. Valentina Carbonara wrote the Abstract and Paragraphs 1, 3, 6.1 and 6.3. Paragraph 7 was written together.
} 
attempting to relate them to previous studies and to analyse their potential implications in terms of language education and policy.

\section{LANGUAGE ATTITUDE: THEORETICAL AND EMPIRICAL ISSUES}

The concept of attitude has held its place for over a century as one of the most important notions in (social) psychology. Its pervasive role in all circumstances has made the attitude an object of interest in numerous fields of research, from sociology to economics, from political science to linguistics. Consequently, different theories, perspectives and methods of analysis have been developed, enriching our knowledge about what attitudes are, and their relationships to different human behaviours. Unfortunately, despite this plethora of information, there is no agreement from either a terminological or semantic perspective. On the one hand, many different terms are used in the literature to refer to attitudes, including in primis judgments, values, beliefs, and ideologies. As Albury (2020) notes, several authors use the terms interchangeably, while others consider ideologies and attitudes part of the beliefs (Spolsky, 2004). On the other hand, the semantic disagreements result in a proliferation of different definitions: Gawronski (2007) argues that the definition of attitude varies according to the degree to which different scholars consider this entity integrated into memory. For example, according to Visser and Mirabile (2004), attitudes are sets of summary evaluations stored in memory; conversely, Schwarz (2007: 639) considers them as «evaluative judgments, formed when needed, rather than enduring personal disposition». Edwards (2004) describes an attitude as a belief amplified by affection, while Gardner (1985: 9) refers to it as «an evaluative reaction to some referent or attitude object, inferred on the basis of the individual's beliefs or opinions about the referent».

In general, it can be said that attitude is a positive or negative feeling for a person, object or issue, developed through social interaction.

The heterogeneity of definitions of attitudes is reflected in an equally broad spectrum of perspectives on what 'language' attitudes are. Garrett (2010) defines language attitude based on Sarnoff's (1970: 279) description of attitude, that is «a disposition to react favourably or unfavourably to a class of object»; in this sense, language attitude reflects the tendency to evaluate a language favourably or unfavourably.

In recent decades, great attention has been paid to research on language attitude and this has greatly contributed to the development of the research field. Language attitude is an umbrella term (Baker, 1992) that refers to different linguistic objects and, in fact, it is possible to distinguish studies in this field in at least three categories (Ianos et al., 2017): the language evaluation paradigm, focused on attitudes towards languages ('named language, including varieties and dialects); the speaker evaluation paradigm, with the focus shifted to the speakers of a language or its varieties (Lambert et al., 1960); and the language learning paradigm (Gardner, 1985), linked to the learning dimension and often explored in relation to motivation.

In this discussion, while considering researches related to the other paradigms, we will focus on the first one, taking as a reference those studies that have languages as the object of the attitude. These works primarily studied bi- or multilingual territories and were carried out using mainly quantitative techniques, for example questionnaires. More specifically, most scholars have used and adapted different versions of the tools provided by Sharp et al. (1973) and Baker (1992). Both conducted in Wales, the latter are seminal papers in the domain of language attitudes. Sharp et al. (1973), in fact, conducted a largescale study, involving 12,000 children between 10 and 14 years of age, to evaluate the attitudes towards English and Welsh. In addition to noting a correlation in the attitudes 
between the two languages, the scholars found that these attitudes were related to linguistic background, age, gender, and length of residence in Wales. They observed how, with increasing age, the positive attitude towards English increases, contrary to what happens with Welsh. Moreover, they found that females have a more positive attitude towards Welsh than males. Baker (1992), in turn, aiming to investigate the attitude towards Welsh and towards bilingualism, administered a questionnaire with a five-point Likert scales to 800 students. Again, several variables were examined and found to be determinant for attitude: linguistic background and proficiency (with students more proficient in Welsh resulting with a more favourable attitude towards this language), age, gender, culture, and type of school.

The effects of gender-related differences in language attitudes have been well documented in different contexts (Burstall, 1975; Dörnyei, Csizér, 2002). Wright (1999), for example, examining the attitude towards French as a foreign language studied in Great Britain notes not only that females have a more favourable attitude than males, but that gender, in a multiple regression, is the most predictive variable.

Another central issue in the analysis of language attitude is related to purely linguistic aspects, in particular linguistic background, and proficiency. On the one hand, several studies have shown how attitudes towards a specific language is influenced by the mother tongue and the language spoken in one's community. This is the case, for example, for English and Maltese as seen in the work of Caruana (2007), or of Spanish and Catalan as found by Huguet (2007: 35), in which «the nearer the family to a given language, the more positive attitudes towards it». On the other hand, language proficiency also seems to be a determining factor for the development of positive attitudes, although the cause-effect relationship between the two is not yet completely evident. This emerges clearly in immigrants with varying degrees of proficiency, as highlighted by Huguet and Janés (2008) in the case of Latin American students who immigrated to Catalonia.

The role of the school and of the different models of plurilingual and intercultural education in language attitudes is also particularly relevant for the purposes of this work. It has been shown that institutional support for a language (and its use in institutional domains, such as the school) affects the social, economic, and linguistic status of a language (O'Rourke, 2011) and, consequently, the attitudes towards it. In the Basque Country, for example, numerous studies have been carried out on attitude towards languages that are part of the curriculum in schools following different educational models (Cenoz, 2001; Etxeberria et al., 2002; Septién, 2006). Generally, these studies highlight a more positive attitude towards all the languages investigated (Spanish, Basque and English) in the schools where Basque is the vehicular language (likely the most multilingual schools).

From the Basque Country also comes the work of Lasagabaster and Sierra (2009) which, comparing the attitude in CLIL (Content and Language Integrated Learning) and Traditional EFL classes (English as a Foreign Language), show how students who are taking part in the CLIL program have a more positive attitude towards the three languages of the curriculum compared to non-CLIL students.

Many studies have also explored teachers' language attitudes, although it is worth observing how «teachers' attitudes about education - about schooling, teaching, learning and students - have generally been referred to as teachers' beliefs» (Pajares, 1992: 316). Among these, a limited but growing number of studies focused on multilingualism and linguistic diversity (De Angelis, 2011; Haukås, 2016; Gorter, Arocena, 2020) and showed that there is a gap between attitudes towards multilingualism, which are generally positive, and real teaching practice, which still excludes the languages that are part of the students' repertoire. 
Regarding the Italian context, studies about language attitude are numerous and involve different languages, including regional variations (De Pascale, Marzo, 2016), and a variety of contexts, such as specific immigrant communities (Guerini, 2009). Moreover, Italian schools, representing students and teachers' attitude towards languages, have been the subject of important works, aimed above all at highlighting an increase in the attitude towards linguistic diversity following the implementation of projects or activities related to multilingual education (Sordella, 2015; Carbonara, Scibetta, 2020b). What should be emphasized, however, is the fact that these studies have a strong qualitative imprint, since the results they reach are obtained through interviews, focus groups and/or observations, differently from what has been done in other countries. Nevertheless, as it will be seen in the next section, the richness of the Italian school, both in terms of students' multilingualism and multilingual educational practices, makes it an ideal context for a systematic analysis of attitudes towards linguistic diversity, as well the reasons behind them.

\section{The Italian CONTEXT Between European LANGUAge policy AND INTERNATIONAL DEBATE OVER MULTILINGUAL EDUCATION}

In Italian schools, 10\% of pupils have a foreign citizenship (MIUR, 2020). Official statistics do not measure the sociolinguistic status of Italian students from an immigrant background (mixed-couple children, second generation students whose parents acquired Italian citizenship, etc.), however we can suppose that emergent bilingual students are a stable and growing presence. The distribution of pupils with a citizenship other than Italian varies across the country, and even though most schools account for percentages lower than $15 \%$ over the total number of students, more than 800 schools have a superdiverse population with half of students presumably speaking languages other than Italian at home.

According to a national investigation, $46 \%$ of children and young people between 6 and 19 years old with a foreign citizenship prefer to speak Italian with family members and more than 88\% use it with friends (Bagna et al., 2018). Local research (Chini, Andorno, 2018) and case studies (Carbonara, 2017) also show the same tendency: heritage languages and identities are endangered by the dominant Italian language, resulting in loss or attrition phenomena in family language(s). One of the last official reports exploring different indicators of 'integration' of immigrant students attending secondary school, claimed that around $63 \%$ of them think in the Italian language (ISTAT, 2020). The results differ across ethnolinguistic communities and they are influenced by individual factors, like age of arrival in Italy. However, the habit of thinking in Italian does not straightforwardly affect school achievement, but the correlation varies according to the different school subjects. Without purposeful interventions the main risk is the loss of linguistic diversity.

In June 2020, the European Commission released the report Education begins with language. In line with the Council's 2019 Recommendation on a comprehensive approach to the teaching and learning of languages, the report underlines the importance of raising the bar for language learning and supporting linguistic diversity. The document describes different countries' initiatives, including language policy strategies based on CLIL, which has been identified as one of the best approaches to enhance language learning outcomes and higher cognitive skills. According to the report, it is also essential to develop functional literacy across all languages spoken by pupils and to step away from monolingual beliefs, through the promotion of language awareness, involving teachers, parents, and the local community. 
The Council of Europe and the European Centre for Modern Languages in the last thirty years have encouraged research and educational initiatives on pluralistic approaches to languages and cultures, referring to «didactic approaches that use teaching/learning activities involving several (i.e., more than one) varieties of languages or cultures» (Council of Europe, 2012: 6).

The first pluralistic approach, 'intercultural education', underpins the entire Italian curriculum and has influenced teachers' methodology in the management of diversity since the '80s (Demetrio, Favaro, 2002). Intercultural education was and still is essential in valuing the different native cultures of immigrant students, promoting reciprocal understanding and respect. However, several scholars have recently questioned those intercultural educational activities which, emphasizing sameness and differences, produce boundaries or stereotypical representations (Dervin, 2012). In the XXI century intercultural education must deconstruct monolithic categorizations and stimulate the interpretation of complexity and the «awareness of our use (or misuse) of representations, strategies, and our own positionings» through hyper-reflexivity (Clark, Dervin, 2014: 27).

The other pluralistic approaches have a more linguistic orientation, and they are 'awakening to languages' or 'éveil aux langues', the 'intercomprehension' of related languages, and 'integrated didactic approaches' to different languages. Allophone students' abilities and identities are recognized and enhanced in the activities based on 'éveil aux langues', which promote language awareness and metalinguistic reflection. One of the main projects aiming at implementing 'éveil aux langues' strategies in primary school was the Evlang programme, supported by the European Commission from 1997 to 2001 (Candelier, 2003) and promoted in different countries, including Italy. Researchers and teachers produced a variety of teaching materials engaging children in the identification of links between languages and cultures, also from an historical perspective, and in the analysis of regularities in phonological and morphosyntactic systems of languages taught in school and belonging to students' language repertoires. Pupils became more aware of the linguistic diversity in their school and social environments, and developed a positive attitude towards diversity and receptive skills to unfamiliar languages (Candelier, 2017).

More recently, the project 'CUNY-NYSIEB' (New York State Initiative on Emergent Bilingual), based on translanguaging pedagogy (García, Li Wei, 2014) has fostered worldwide research and teaching experiences on multilingual education. Translanguaging theory/practice questions traditional bilingual and dual language programs which enforce language separation, adopting the perspectives of the dominant group. According to García and Otheguy (2021) immigrant minoritized children will be able to engage in competent performances at school only by making the new features of the school language part of a recognized repertoire which includes their own individual and community markings. Thus, teachers must provide opportunities for students to develop their entire language repertoire for meaning-making, knowledge construction and academic purposes. CUNY-NYSIEB researchers and teachers have published a variety of teaching materials and guides describing the 'translanguaging classroom', introducing several strategies to engage students' multilingual resources in oracy and literacy activities (García et al., 2017). Linguistic schoolscape (Brown, 2012; Bellinzona, 2021) also has a significant role in CUNY-NYSIEB project: in order to develop a multilingual ecology, schools made an effort to incorporate and make visible students' repertoires: a variety of signs, labelling, posters and materials have been produced integrating minoritized languages for educational and ideological purposes (Menken et al., 2018).

Even though the most recent Italian national guidelines regarding students with an immigrant background (MIUR, 2014) and education policy (MIUR, 2018) value multilingualism and multiculturalism, top-down initiatives building on the more linguistic 
oriented pluralistic approaches to languages and cultures or on translanguaging pedagogy are still limited. Analysing a recent report regarding bottom-up actions in the field of language education (ISMU, 2021) it is possible to identify four different approaches addressing immigrant minority students or languages: innovative activities based on teaching/learning of Italian language, intercultural education, the introduction of extracurricular courses of non-European languages considered prestigious (Arabic, Chinese, Russian, etc) and translanguaging pedagogy. The report also mentions different CLIL initiatives involving mainly curricular languages, but also historical Italian minority languages.

The collaboration between universities and schools has been essential to promote projects based on multilingual education. In the domain of 'éveil aux langues', for instance, the University of Turin has conducted multilingual activities in several primary schools since 2015 (Sordella, Andorno, 2017). Languages like Romanian, Spanish, Portuguese and various dialects have been included in activities based on intercomprehension addressing primary and secondary students, usually with the coordination of academic teams and European resources (cf. Cognigni, 2020 for a complete review). The University for Foreigners of Siena leads the project 'L'AltRoparlante', which involves six schools, from kindergarten to lower secondary level, in four different regions. Translanguaging pedagogy, combined with 'awakening to languages' approach has been integrated in curricular activities, leveraging immigrant minority students' multilingual repertoires (Carbonara, Scibetta, 2020a).

These initiatives have been created to promote an ecological language policy in the schools involved and to raise students' and teachers' awareness of multilingual practices and minoritized languages. Even if the contribution to the field generated by these projects is considerable, it is fundamental to broaden the investigations beyond the prospective offered by case studies and to incorporate quantitative measures. The present study intends to pursue this objective.

\section{Methodology}

This study is part of a larger ongoing research project of the University for Foreigners of Siena, aimed at investigating multilingualism and language policies in the Italian school, with a particular focus on the uses and functions of the schoolscape (Bellinzona, 2021). This project presents an articulated research design, which involves the use of mixed methods (Creswell, 2008), and both quantitative and qualitative tools, which are then combined to triangulate the results (Creswell et al., 2003). These tools, used in a sample of 12 schools, investigated as multiple case studies (Stake 2005), include:

- visual data of the schoolscape, collected through the tourist guide technique (Szabó, 2015) and analysed, quantitatively, and qualitatively, taking into account 21 different indicators. These indicators refer to five thematic areas: informative, linguistic, multimodality, purpose, agency. Among the indicators belonging to the 'purpose' area, there is the variable of genre, which we have categorized into 10 different types, conforming to their communicative intentions. One of the sign types identified has been labelled as 'pluralistic', which includes all the signs created within teaching activities and refers to the cultural and linguistic heterogeneity of schools and society, to the celebration of different origins, ethnicities, languages, cultures, and traditions, thus explicitly aiming at developing intercultural competence.

- field notes;

- semi-structured interviews, conducted with principals, language teachers and teachers responsible for intercultural education, and analysed in accordance with the principles 
of Grounded Theory (Charmaz, 2006) and qualitative content analysis (Mayring, 2004) through NVivo 12 Pro;

- questionnaires administered to teachers and students.

In this article reference will be made exclusively to what emerged from the questionnaires administered to the students. However, the results obtained with the other tools were used to create some variables, useful for the analyses that follow (cf. Bellinzona, 2021; Bagna, Bellinzona, forthcoming).

\subsection{Hypotheses}

As anticipated in the Introduction, this study explores attitudes towards linguistic diversity of students attending Italian secondary schools, investigating the factors (both individual and related to the school context) which can influence and predict these attitudes. In order to pursue these aims and considering the theoretical and contextual framework, the following hypotheses were established:

- H1 Attitudes toward linguistic diversity will be influenced by gender.

- H2 Attitudes toward linguistic diversity will be influenced by school grade.

- H3 Attitudes toward linguistic diversity will be correlated to linguistic repertoire.

- H4 Attitudes toward linguistic diversity will be influenced by origin.

- H5 Considered simultaneously, the variables will have different explanatory powers regarding the attitudes toward linguistic diversity.

- H6 Attitudes toward linguistic diversity will be influenced by contextual linguistic diversity.

- H7 Attitudes toward linguistic diversity will be influenced by plurilingual and intercultural strategies.

- H8 Attitudes toward linguistic diversity will be influenced by quantitative use of the schoolscape.

- H9 Attitudes toward linguistic diversity will be influenced by qualitative use of the schoolscape.

\subsection{Instruments and procedures}

The instrument was chosen according to the research tradition established in the field of attitudes. For the creation of the questionnaire, the recommendations of Oppenheim (1992), Brown (2001) and Dörnyei $(2003 ; 2007)$ were considered. With this in mind, some essential guidelines have been formulated:

1. The general characteristics of the questionnaires have been established as to length, format, layout and main sections. We followed the suggestions for the timing of compilation, which indicate a maximum time of 30 minutes (Dörnyei, 2003, 2007).

2. Drawing from a previously larger number of items, we selected No. 41 statements, including an equal number with positive and negative wording. The formulation and choice of the items were made considering the research questions and what emerged from the literature review. At the basis of the design there are also the criteria of immediacy and simplicity (Ellard, Rogers, 1993). The items were mixed, while respecting the thematic subdivision, and both general and specific instructions have been written. 
3. Before the dissemination, a pilot version of the questionnaire was administered to a small group of lower secondary students, in order to obtain feedback on the clarity of the items, avoid errors and misunderstandings and make, where necessary, changes and improvements. After reviewing the pilot's results, some items were slightly modified.

The questionnaire, in its final version, consists of two parts: the first aimed at obtaining background information on participants, and the second aimed at investigating awareness and attitudes. For the identification of the questions in the first section, reference was made, inter alia, to Siebetcheu (2018). Therefore, some demographic data (gender, age), the languages known (at any level) and the patterns of linguistic use in three different domains (family, school, friends) were requested. Then, only the school context was examined in order to investigate its role in the processes of language contact. Therefore, the participants were asked to indicate the languages spoken by classmates (to assess the level of awareness) and their willingness to learn one or more of them (curiosity). They were further asked to fill in a blank space with any words or expressions in their peers' home languages already learned, independently or within school activities.

The second section of the questionnaire consists of No. 41 items, divided into four macro-areas, formulated on a 5-points Likert scale, «the most popular scaling procedure» (Oppenheim, 1992: 195), from 'Strongly disagree' to 'Strongly agree'. The four areas focus on the following topics:

a) attitudes towards linguistic diversity (Items 1-14);

b) attitudes towards cultural diversity (Items 15-26);

c) awareness and attitudes towards linguistic diversity in the linguistic landscape (Items 27-32);

d) awareness and attitudes towards linguistic diversity in the schoolscape (Items 33-41).

In this article we will focus only on the first area. The items that make up this scale aim to elicit students' attitudes towards linguistic diversity both from a general point of view and in the school context. Unlike what has been done by almost all the studies on language attitudes, however, we did not want to investigate the attitudes towards the individual languages that are part of students' repertoires. As claimed by Cook (2006), Cenoz (2009) and Dewaele (2010), in fact, we believe that research on multilingualism should be autonomous and not be based on monolingual parameters. Adopting, therefore, a holistic approach to language attitudes, we considered it appropriate to choose and formulate the items according to a heterolinguistic perspective.

The questionnaires were distributed and filled out during school hours in the presence of the researcher. The spaces, times and classes in which the data was collected were planned and agreed upon with specific contact people. Consent was obtained from all participants prior to the study's commencement, and every ethical requirement has been fulfilled.

\subsection{Statistical treatment}

The data collected were analysed using the SPSS v.23 package, IBM's statistical analysis software. First, the negative items of the Likert scale were transformed through the recoding procedure; consequently, the scores expressed for the negatively worded statements were reversed (Items 2, 4, 5, 7, 8, 13, 14). After that, the mean score of each item was calculated and they were computed into a new variable, related to the attitude towards linguistic diversity (AT'TLing). 
A reliability assessment of the instrument's ability to measure students' attitudes accurately and consistently was carried out using Chronbach's Alpha test. Alpha coefficient scores for both the entire questionnaire and the language attitude section were obtained and were respectively equal to .87 and .71 . Usually, in social science research a reliability coefficient higher than .70 is considered acceptable and, consequently, the constructs are treated as valid (Huck, 2012). The fact that the language attitude section has a lower score than the entire questionnaire is justified by the reduced number of items. Despite this, the result obtained can be considered quite good (Dörnyei, Csizér, 2002).

Finally, several parametric (regressions, correlations, T-tests, ANOVA tests) and nonparametric (Kruskal-Wallis H Test) procedures, which reflect the multiplicity of data types used (ordinal, category, and scalars), were carried out in order to generate appropriate data for the purpose of the study.

\section{SAMPLE}

\subsection{Schools part of the survey}

For the realization of this study, 12 lower and upper secondary schools were selected throughout the country. Tab. 1 shows grade (lower and upper), location, number of students, percentage of pupils with a migratory background, which languages are part of the curriculum and the most widely used plurilingual and intercultural education strategies for each school. The information reported was obtained from the official documents provided by the schools and from their corresponding websites. In addition to these sources, we took into consideration what emerged from the analysis of the interviews.

It is important to recognize that one approach does not exclude the other. Very often, in fact, schools in which a CLIL program is active also include activities related to intercultural education. In turn, schools with a strong propensity for intercultural education often include activities with a more plurilingual tendency. We specify that S.2, the only one in the sample belonging to the group 'éveil aux langues'/translanguaging, is a school in which both approaches have been applied in combination for years. Nonetheless, it appeared useful for the analysis to identify the main approach, the one on which teachers and principals interviewed have placed greater emphasis and attention.

Table 1. Schools characteristics - Information from schools' official documents and interviews

\begin{tabular}{|l|c|l|c|c|l|l|}
\hline School & Grade & Region & $\begin{array}{c}\text { No. } \\
\text { Pupils }\end{array}$ & $\begin{array}{c}\text { \% pupils with } \\
\text { immigrant } \\
\text { background }\end{array}$ & $\begin{array}{c}\text { Foreign } \\
\text { languages in } \\
\text { the } \\
\text { curriculum }\end{array}$ & $\begin{array}{c}\text { Plurilingual } \\
\text { and } \\
\text { intercultural } \\
\text { strategy }\end{array}$ \\
\hline S. 1 & L & Tuscany & 427 & $12 \%$ & $\begin{array}{l}\text { Engl, Fr, Sp, } \\
\text { Ger }\end{array}$ & $\begin{array}{l}\text { Intercultural } \\
\text { education }\end{array}$ \\
\hline S. 2 & L & Piedmont & 126 & $40 \%$ & Engl, Fr & $\begin{array}{l}\text { Éveil aux } \\
\text { langues/ } \\
\text { translanguaging }\end{array}$ \\
\hline S. 3 & U & Marche & 350 & $14 \%$ & Engl & $\begin{array}{l}\text { Sporadic } \\
\text { interventions }\end{array}$ \\
\hline S. 4 & U & Tuscany & 674 & $21 \%$ & Engl, Fr, Ger & $\begin{array}{l}\text { Intercultural } \\
\text { education }\end{array}$ \\
\hline
\end{tabular}


(C) Italiano LinguaDue 2. 2021. M. Bellinzona, V. Carbonara, Secondary students' attitudes towards linguistic diversity: an investigation on individual and educational aspects in Italian schools

\begin{tabular}{|l|c|c|c|c|l|l|}
\hline S. 5 & L & Lazio & 195 & $30 \%$ & Engl, Fr & $\begin{array}{l}\text { Sporadic } \\
\text { interventions }\end{array}$ \\
\hline S. 6 & U & Lombardy & 847 & $60 \%$ & $\begin{array}{l}\text { Engl, Fr, Sp, } \\
\text { Ger }\end{array}$ & $\begin{array}{l}\text { Intercultural } \\
\text { education }\end{array}$ \\
\hline S. 7 & L & Veneto & 185 & $29 \%$ & Engl, Sp & $\begin{array}{l}\text { Intercultural } \\
\text { education }\end{array}$ \\
\hline S. 8 & U & Piedmont & 676 & $70 \%$ & Engl & $\begin{array}{l}\text { Sporadic } \\
\text { interventions }\end{array}$ \\
\hline S. 9 & U & $\begin{array}{c}\text { Emilia } \\
\text { Romagna }\end{array}$ & 1398 & $8 \%$ & $\begin{array}{l}\text { Engl, Fr, Sp, } \\
\text { Ger }\end{array}$ & CLIL \\
\hline S. 10 & L & Lazio & 491 & $11 \%$ & Engl, Fr, Sp & $\begin{array}{l}\text { Sporadic } \\
\text { interventions }\end{array}$ \\
\hline S. 11 & L & Sicily & 180 & $18 \%$ & Engl, Fr & $\begin{array}{l}\text { Intercultural } \\
\text { education }\end{array}$ \\
\hline S. 12 & U & Calabria & 824 & $3 \%$ & Engl, Fr, Sp & CLIL \\
\hline
\end{tabular}

Tab. 2, in turn, shows the classification of schools based on the characteristics of the schoolscape. Firstly, a purely quantitative aspect of the schoolscape was considered and the number of signs documented during the survey was recorded. Schools were, therefore, divided according to whether they had rich schoolscapes with over 150 signs, schoolscapes with artifacts between 100 and 150, or basically bare schoolscape, with fewer than 100 signs observed (Bellinzona, 2021). Secondly, reference was made to the qualitative element, thus considering the percentage of 'pluralistic' signs out of the total of those documented. The schools were divided into two groups, depending on whether the percentage of these artifacts was higher or lower than 10 .

Table 2. Schoolscape characteristics according to schools

\begin{tabular}{|l|c|c|}
\hline School & No. Signs & \% pluralistic signs \\
\hline S. 1 & $>150$ & $>10 \%$ \\
\hline S. 2 & $>150$ & $>10 \%$ \\
\hline S. 3 & $<100$ & $<10 \%$ \\
\hline S. 4 & $>150$ & $>10 \%$ \\
\hline S. 5 & $<100$ & $<10 \%$ \\
\hline S. 6 & $100-150$ & $>10 \%$ \\
\hline S. 7 & $100-150$ & $<10 \%$ \\
\hline S. 8 & $<100$ & $<10 \%$ \\
\hline S. 9 & $<100$ & $<10 \%$ \\
\hline S. 10 & $100-150$ & $<10 \%$ \\
\hline S. 11 & $>150$ & $<10 \%$ \\
\hline S. 12 & $>150$ & $>10 \%$ \\
\hline
\end{tabular}


(C) Italiano LinguaDue 2. 2021. M. Bellinzona, V. Carbonara, Secondary students' attitudes towards linguistic diversity: an investigation on individual and educational aspects in Italian schools

\subsection{Participants}

The participants in the study were 642 students. Tab. 3 shows the distribution of the classes in which the questionnaire was administered, as well as the absolute number and percentage of questionnaires collected in each school over the total amount of the sample.

Table 3. Number and percentage of questionnaires collected according to schools

\begin{tabular}{|l|c|c|c|}
\hline School & No. Classes & No. of questionnaires & Percentage of questionnaires \\
\hline S. 1 & 3 & 64 & $10.0 \%$ \\
\hline S. 2 & 2 & 37 & $5.8 \%$ \\
\hline S. 3 & 3 & 54 & $8.4 \%$ \\
\hline S. $\mathbf{4}$ & 4 & 66 & $10.3 \%$ \\
\hline S. 5 & 2 & 38 & $5.9 \%$ \\
\hline S. 6 & 5 & 75 & $11.7 \%$ \\
\hline S. 7 & 3 & 39 & $6.1 \%$ \\
\hline S. 8 & 4 & 53 & $8.3 \%$ \\
\hline S. 9 & 3 & 55 & $8.6 \%$ \\
\hline S. 10 & 3 & 60 & $9.3 \%$ \\
\hline S. 11 & 3 & 23 & $3.6 \%$ \\
\hline S. 12 & 4 & 78 & $12.1 \%$ \\
\hline Tot. & 39 & 642 & $100 \%$ \\
\hline
\end{tabular}

Regarding gender, No. 338 participants are female (52.6\%), No. 297 male (46.3\%) and No. 7 prefer not to specify. Regarding age, No. 213 informants are between 11 and 13 (33\%), No. 209 between 14 and 16 (33\%), No. 205 from 17 to 21 (32\%) and No. 15 do not complete the field $(2 \%)$.

Of the sample, No. 224 informants $(35 \%)$ have a migratory background, marked also from the point of view of different linguistic uses within the family.

As far as linguistic repertoires are concerned, as can be seen from Fig. 1, only No. 15 informants $(2.3 \%)$ declare that they know (at any level) a single language.

Reduced absolute numbers (and percentages) are also observed for lower and upper rank positions, with No. 35 informants $(5.4 \%)$ reporting the presence of two languages in their linguistic space, No. 56 students $(8.7 \%)$ claiming to know six languages, and No. $32(5.0 \%)$ up to seven.

Most informants declared that they have between three and five languages in their repertoire, respectively No. $109(17.0 \%)$ three languages, No. 235 (36.6\%) four languages and No. $158(24.6 \%)$ five languages. 
(C) Italiano LinguaDue 2. 2021. M. Bellinzona, V. Carbonara, Secondary students' attitudes towards linguistic diversity: an investigation on individual and educational aspects in Italian schools

Figure 1. Number of languages part of students' repertoire

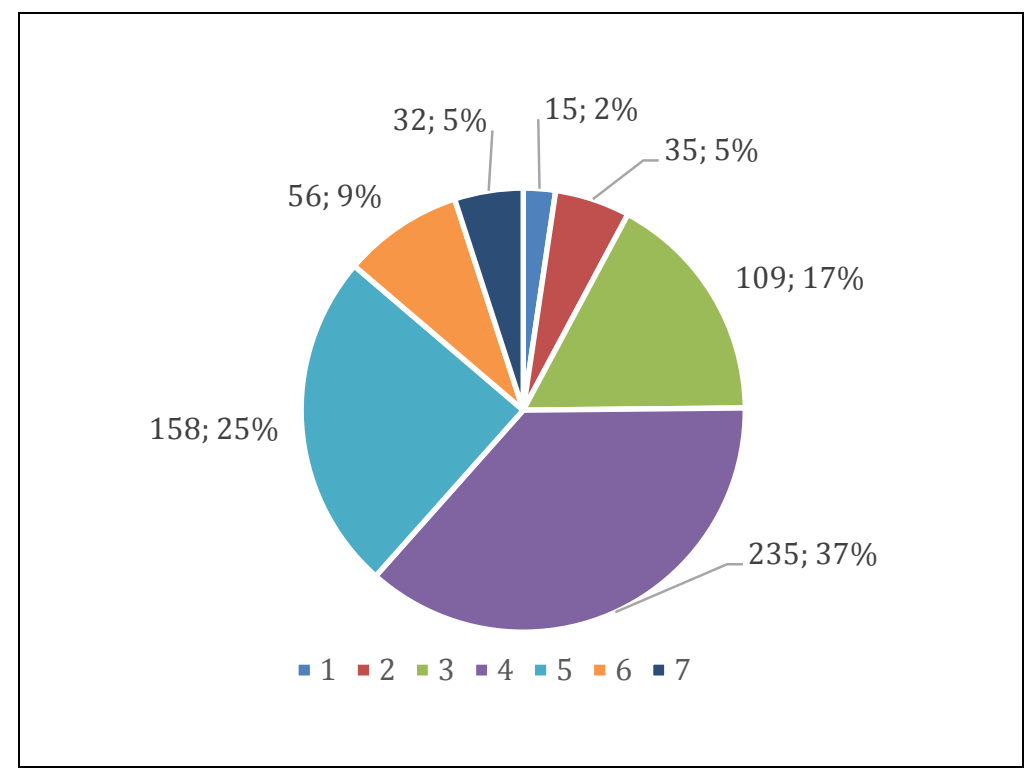

The questionnaire also documented, on a qualitative level, which languages are part of the students' linguistic repertoires. In total, 49 different languages and varieties have been reported, making evident once again the great diversity of the Italian linguistic space and the neo-plurilingualism characteristic of the Italian school today. Tab. 4 reports the data of the 10 languages most frequently declared by informants.

Table 4. Top ten languages by frequency declared as part of students' repertoires $(n=642)$

\begin{tabular}{|l|l|c|c|}
\hline No. Fr. & \multicolumn{1}{|c|}{ Language } & No. & \% \\
\hline 1 & Italian & 636 & $99.1 \%$ \\
\hline 2 & English & 581 & $90.5 \%$ \\
\hline 3 & French & 442 & $68.8 \%$ \\
\hline 4 & Dialect & 352 & $54.8 \%$ \\
\hline 5 & Spanish & 292 & $45.5 \%$ \\
\hline 6 & German & 87 & $13.6 \%$ \\
\hline 7 & Arabic & 65 & $10.1 \%$ \\
\hline 8 & Albanian & 46 & $7.2 \%$ \\
\hline 9 & Romanian & 45 & $7.0 \%$ \\
\hline 10 & Chinese & 25 & $3.9 \%$ \\
\hline
\end{tabular}


(C) Italiano LinguaDue 2. 2021. M. Bellinzona, V. Carbonara, Secondary students' attitudes towards linguistic diversity: an investigation on individual and educational aspects in Italian schools

\section{RESULTS}

\subsection{Descriptive analysis}

In this section we will provide a descriptive overview of the results related with Items 1-14 of the questionnaire and the associated variable 'Attitude toward linguistic diversity' (cfr. Par. 4).

Tab. 5 shows percentages for each possible answer and the mean scores for each single Likert-scale item employed to compute the variable 'Attitude toward linguistic diversity'. For the negative Items 2, 4, 5, 7, 8, 13 and 14 we reported here the actual means before the reverse operation.

Table 5. Percentages and mean scores related with the answers provided for Items 1-14

\begin{tabular}{|l|c|c|c|c|c|c|}
\hline Questions & $\begin{array}{l}\text { I strongly } \\
\text { disagree }\end{array}$ & I disagree & $\begin{array}{c}\text { Neither } \\
\text { agree nor } \\
\text { disagree }\end{array}$ & I agree & $\begin{array}{c}\text { I strongly } \\
\text { agree }\end{array}$ & $\begin{array}{c}\text { Mean } \\
\text { (max. 5) }\end{array}$ \\
\hline $\begin{array}{l}\text { 1. The more languages you } \\
\text { know, the easier it is to } \\
\text { learn others }\end{array}$ & $3.5 \%$ & $9.4 \%$ & $33 \%$ & $36.6 \%$ & $17.5 \%$ & 3.55 \\
\hline $\begin{array}{l}* 2 . \text { If the entire world } \\
\text { spoke the same language, } \\
\text { it would be easier to live in } \\
\text { peace }\end{array}$ & $10.7 \%$ & $17.5 \%$ & $29.2 \%$ & $21.8 \%$ & $20.7 \%$ & 3,24 \\
\hline $\begin{array}{l}\text { 3. I think it would be nice } \\
\text { if we all studied different } \\
\text { languages }\end{array}$ & $6.5 \%$ & $12.9 \%$ & $25.1 \%$ & $29.5 \%$ & $26 \%$ & 3,56 \\
\hline $\begin{array}{l}* 4 . \text { I think it would be } \\
\text { better to study in a class } \\
\text { where everyone speaks the } \\
\text { same language }\end{array}$ & $17.3 \%$ & $20.8 \%$ & $22.7 \%$ & $19.4 \%$ & $19.8 \%$ & 3,04 \\
\hline $\begin{array}{l}* 5 . \text { It is better to learn } \\
\text { English well than to study } \\
\text { several different languages }\end{array}$ & $12.6 \%$ & $20.1 \%$ & $28 \%$ & $25.2 \%$ & $14.2 \%$ & 3,08 \\
\hline $\begin{array}{l}\text { 6. Those who live in Italy } \\
\text { should be able to keep } \\
\text { their mother tongue }\end{array}$ & $6.6 \%$ & $8.8 \%$ & $22.6 \%$ & $28.4 \%$ & $33.5 \%$ & 3,73 \\
\hline $\begin{array}{l}* 7 . \text { I think English is the } \\
\text { most important language } \\
\text { to learn today }\end{array}$ & $4.3 \%$ & $5.8 \%$ & $16.4 \%$ & $34.1 \%$ & $39.4 \%$ & 3,99 \\
\hline $\begin{array}{l}* 8 . \text { Those who live in Italy } \\
\text { must learn Italian, even if } \\
\text { it means forgetting their } \\
\text { own native language }\end{array}$ & $23 \%$ & $25.6 \%$ & $30.3 \%$ & $12.6 \%$ & $7.6 \%$ & 2,55 \\
\hline $\begin{array}{l}\text { 9. I am interested when in } \\
\text { class it happens to make } \\
\text { references to languages } \\
\text { other than those we study }\end{array}$ & $3.2 \%$ & $5.9 \%$ & $19.9 \%$ & $47.3 \%$ & $23.7 \%$ & 3,83 \\
\hline $\begin{array}{l}\text { 10. I think everyone } \\
\text { should be able to use their } \\
\text { home language in school }\end{array}$ & $9.8 \%$ & $9.9 \%$ & $28.4 \%$ & $27.9 \%$ & $24 \%$ & 3,46 \\
\hline
\end{tabular}


(C) Italiano LinguaDue 2. 2021. M. Bellinzona, V. Carbonara, Secondary students' attitudes towards linguistic diversity: an investigation on individual and educational aspects in Italian schools

\begin{tabular}{|l|l|l|l|l|l|l|}
\hline $\begin{array}{l}\text { 11. I think linguistic } \\
\text { diversity in the classroom } \\
\text { is good }\end{array}$ & $6.2 \%$ & $6.3 \%$ & $19.6 \%$ & $34 \%$ & $33.9 \%$ & 3,83 \\
\hline $\begin{array}{l}\text { 12. Different languages } \\
\text { allow you to see the world } \\
\text { with different eyes }\end{array}$ & $4.7 \%$ & $6 \%$ & $14.5 \%$ & $34.8 \%$ & $40 \%$ & 3,99 \\
\hline $\begin{array}{l}* 13 . \text { I think that at school } \\
\text { we should speak only in } \\
\text { Italian }\end{array}$ & $29.7 \%$ & $26.6 \%$ & $22.6 \%$ & $10.4 \%$ & $10.6 \%$ & 2,46 \\
\hline $\begin{array}{l}* 14 . \text { At school we already } \\
\text { study two (or three) } \\
\text { languages: we do not need } \\
\text { to know new ones }\end{array}$ & $40.8 \%$ & $27.8 \%$ & $15 \%$ & $7.6 \%$ & $8.8 \%$ & 2,16 \\
\hline
\end{tabular}

The statements which received the largest agreement, Item 7 and Item 12, suggest two different (but not necessarily diverging) perspectives towards multilingualism. However, the items which obtained the lowest agreement (13 and 14), show that generally participants are favourable to a multilingual school environment. Around $71 \%$ of the students are interested when teachers or peers make connections to languages not included in the curriculum (Item 9) and almost 68\% think that the linguistic diversity in class is a resource (Item 11). Results regarding Items 6 and 8, which are related to immigrant students' linguistic repertoires, highlight that the informants generally have a respectful attitude towards language rights: only $15.4 \%$ of the students strongly disagree or disagree with the right to maintain native immigrant languages and an overall $20.2 \%$ support a subtractive bilingualism policy for people with an immigrant background. Finally, less than $20 \%$ of the participants dissent from the possibility of engaging home languages at school (Item 10).

Tab. 6 displays the results related with the computed variable 'Attitude towards linguistic diversity' across different groups. The participants' language attitude was found to be quite high $(\mathrm{M}=3.38)$. Students from an immigrant background have a more positive attitude towards linguistic diversity compared to native Italian students. Students attending a school with more than $30 \%$ of students with a citizenship other than Italian (S.2, S.5, S.6, S.8) have a slightly better attitude than students attending schools with a lower percentage of students from an immigrant background.

Table 6. "Attitudes towards linguistic diversity" across different groups

\begin{tabular}{|l|c|c|c|}
\hline & N & $\begin{array}{c}\text { Mean } \\
\text { (max. 5) }\end{array}$ & SD \\
\hline Total sample & 637 & 3.38 & .54 \\
\hline Native Italian students & 415 & 3.35 & .52 \\
\hline Students from an immigrant background & 222 & 3.47 & .57 \\
\hline $\begin{array}{l}\text { Participants attending schools with }<30 \% \text { students from an } \\
\text { immigrant background }\end{array}$ & 437 & 3.36 & .51 \\
\hline $\begin{array}{l}\text { Participants attending schools with }>30 \% \text { students from an } \\
\text { immigrant background }\end{array}$ & 200 & 3.44 & .59 \\
\hline
\end{tabular}


Tab. 7 shows language attitude ranking across the different schools involved in the research. Comparing the results with the school characteristics (cf. Paragraph 5.1), the three schools with the highest scores applied different plurilingual and intercultural strategy (S2: 'éveil aux langues'/translanguaging; S12: CLIL; S6: intercultural education), while in the schools which obtained the lowest results in language attitude (S3, S8), multilingual education practices are sporadic. Three upper secondary schools are placed at the bottom of the ranking (S3, S8, S4), and five out of six schools with a language attitude score above the average have a linguistic schoolscape with more than $10 \%$ of pluralistic signs (S2, S12, S6, S10, S9).

Table 7. School ranking according to "Attitude towards linguistic diversity" score

\begin{tabular}{|c|c|c|}
\hline School & Mean & SD \\
\hline S.2 & 3.85 & 0.61 \\
\hline S.12 & 3.67 & 0.41 \\
\hline S.6 & 3.51 & 0.44 \\
\hline S.5 & 3.47 & 0.42 \\
\hline S.10 & 3.45 & 0.43 \\
\hline S.9 & 3.40 & 0.54 \\
\hline Average & 3.38 & 0.54 \\
\hline S.1 & 3.37 & 0.46 \\
\hline S.7 & 3.33 & 0.51 \\
\hline S.11 & 3.25 & 0.42 \\
\hline S.4 & 3.21 & 0.50 \\
\hline S.8 & 3.04 & 0.64 \\
\hline S.3 & 2.98 & 0.53 \\
\hline
\end{tabular}

In the next paragraphs we will investigate which specific variables have a significant impact or predict language attitude.

\subsection{Individual indicators and predictors of attitude towards linguistic diversity}

In this section we will consider the variables inherent in the individual subjects that we have hypothesized may influence the attitude towards linguistic diversity:

- Gender: male vs female.

- Age: grade, upper vs lower.

- Origin: immigrant background, yes vs no.

- N. Languages: n. of languages in the students' linguistic repertoire.

Regarding the first three variables, Student's t-tests, preceded by the check of the assumptions of normality and homogeneity of variance, were carried out to compare the means of the different groups. The results, reported in Tab. 8, showed a significant difference in the attitude between all the groups considered. 
(C) Italiano LinguaDue 2. 2021. M. Bellinzona, V. Carbonara, Secondary students' attitudes towards linguistic diversity: an investigation on individual and educational aspects in Italian schools

Table 8. Independent-Samples T-Test Summary Table for gender, age, origin

\begin{tabular}{|c|c|c|c|c|c|c|}
\hline \multirow[b]{4}{*}{$\begin{array}{l}\text { Attitudes towards } \\
\text { linguistic diversity }\end{array}$} & \multicolumn{6}{|c|}{ Gender } \\
\hline & \multicolumn{2}{|c|}{ Male } & \multicolumn{2}{|c|}{ Female } & \multirow[b]{2}{*}{$\mathrm{p}$} & \multirow[b]{2}{*}{ df } \\
\hline & M & $\mathrm{SD}$ & M & $\mathrm{SD}$ & & \\
\hline & 3.18 & .55 & 3.56 & .48 & $<.001$ & 581 \\
\hline & \multicolumn{4}{|c|}{ Age - grade } & & \\
\hline & \multicolumn{2}{|c|}{ Upper } & \multicolumn{2}{|c|}{ Lower } & & \\
\hline & M & $\mathrm{SD}$ & M & $\mathrm{SD}$ & $\mathrm{p}$ & df \\
\hline & 3.34 & .56 & 3.46 & .51 & .006 & 635 \\
\hline & \multicolumn{6}{|c|}{ Origin - immigrant background } \\
\hline & \multicolumn{2}{|l|}{ Yes } & \multicolumn{2}{|l|}{ No } & & \\
\hline & $\mathrm{M}$ & SD & M & SD & $\mathrm{p}$ & $\mathrm{df}$ \\
\hline & 3.47 & .57 & 3.35 & .52 & .005 & 632 \\
\hline
\end{tabular}

Therefore, a significant difference was found between the attitude of males and females, $\mathrm{t}(581.125)=9,137, \mathrm{p}<.001$; of upper and lower secondary school students, $\mathrm{t}$ $(635)=2.738, \mathrm{p}=.006$; and of students with or without migratory background, $\mathrm{t}(632)=$ $-2.827, \mathrm{p}=.005$.

As regards linguistic repertoires, we used Pearson's correlation to examine how the number of known languages relates to the attitude towards linguistic diversity. The results show that the two variables are significantly and positively correlated with each other, $r$ $(637)=.200, \mathrm{p}<.001$. Consequently, as the number of languages in the repertoire increases, so does the attitude.

In order to determine the effects of these variables predicting the attitude, multiple regressions analysis was conducted. In the first place, the assumptions of normality, independence and multicollinearity of the residues were verified. Fig. 2 shows the nonviolation of these assumptions.

Figure 2. Assumptions of normality, independence and multicollinearity

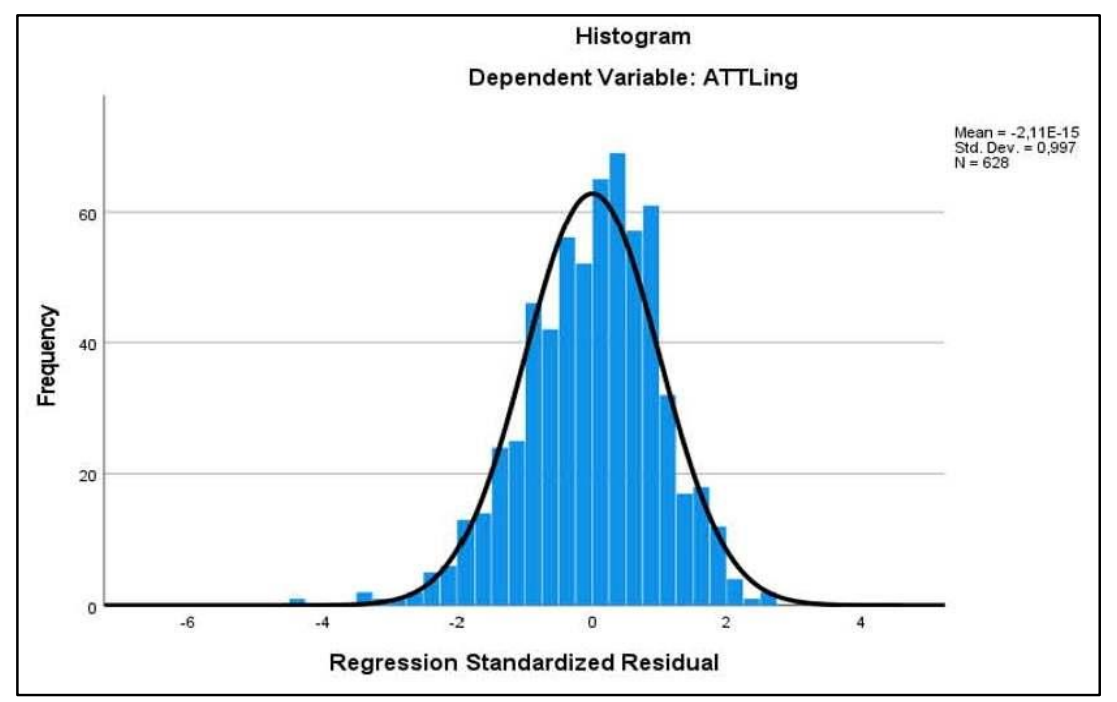


(C) Italiano LinguaDue 2. 2021. M. Bellinzona, V. Carbonara, Secondary students' attitudes towards linguistic diversity: an investigation on individual and educational aspects in Italian schools

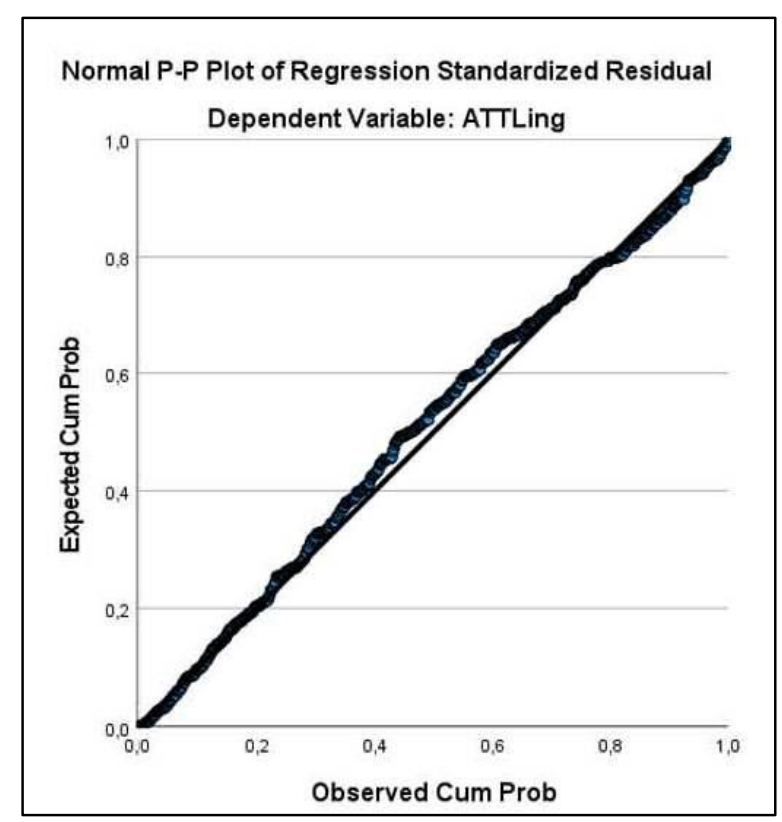

The independence of the residues was verified through the Durbin-Watson statistic (D.W. = 1.64), and multicollinearity was tested through tolerance and inflation coefficients (VIF) (Tab. 9). All the values and coefficients found are within the allowed threshold: D.W. in the range of 1.5 to 2.5 , for tolerance values higher than 0.1 , and for inflation values less than 10 (Field, 2009).

Table 9. Individual factors weight in the total attitude regression model

\begin{tabular}{|l|c|c|c|c|c|c|}
\hline & $\begin{array}{c}\text { Unstandardized } \\
\text { Coefficients B }\end{array}$ & $\begin{array}{c}\text { Std. } \\
\text { Error }\end{array}$ & $\mathbf{t}$ & Sig. & Tolerance & VIF \\
\hline Constant & 3.329 & 0.080 & 41.426 & $<0.001$ & & \\
\hline $\begin{array}{l}\text { Gender (male } \\
\text { vs female) }\end{array}$ & -0.334 & 0.041 & -8.087 & $<0.001$ & 0.946 & 1.057 \\
\hline $\begin{array}{l}\text { Grade (second } \\
\text { vs first) }\end{array}$ & -0.107 & 0.041 & -2.614 & 0.009 & 0.991 & 1.009 \\
\hline N. Languages & 0.057 & 0.016 & 3.483 & $<0.001$ & 0.936 & 1.068 \\
\hline $\begin{array}{l}\text { Immigrant } \\
\text { background } \\
\text { (yes vs no) }\end{array}$ & 0.105 & 0.042 & 2.502 & 0.013 & 0.989 & 1.011 \\
\hline
\end{tabular}

This regression model was significant, $\mathrm{F}(4,623)=27.892 ; \mathrm{p}<.001$; adjusted $\mathrm{R} 2=$ 0.14 .

In this equation line, all the variables were significant predictors, two of them having negative weights and two a positive weight: gender $(\mathrm{t}=-8.087 ; \mathrm{p}<.001)$, school grade $(\mathrm{t}=-2.614 ; \mathrm{p}=.009)$, number of languages known $(\mathrm{t}=3.483 ; \mathrm{p}<.001)$ and the immigrant background $(\mathrm{t}=2.502 ; \mathrm{p}=.013)$. The regression equation is formed by the constant and its corresponding explanatory variables:

$$
y_{0}=3.329-0.334 \text { Gender }-0.107 \text { Grade }+0.057 \text { Languages + 0.105 Migration }
$$


(C) Italiano LinguaDue 2. 2021. M. Bellinzona, V. Carbonara, Secondary students' attitudes towards linguistic diversity: an investigation on individual and educational aspects in Italian schools

\subsection{Educational strategies affecting the attitude towards linguistic diversity}

In this section we will consider the following variables:

- Plurilingual and intercultural strategies: 'éveil aux langues'/translanguaging; CLIL; intercultural education; sporadic interventions.

- Number of signs displayed in the linguistic schoolscape: less than 100; between 100 and 150; more than 150 .

- Percentage of pluralistic signs in the linguistic schoolscape: less or more than $10 \%$ of the total amount of signs.

- Presence of students from an immigrant background: less or more than $30 \%$ of the total student population.

As displayed in Tab. 10, attitude score varies across the schools according to the 'Plurilingual and intercultural strategies' groups. In order to determine whether the instructional approaches adopted by the schools involved in the study have a significant impact on students' attitude towards linguistic diversity, we conducted a One-Way ANOVA.

Table 10. Descriptive statistic for Attitude towards linguistic diversity according to Plurilingual and Intercultural Strategies

\begin{tabular}{|l|c|c|}
\hline \multicolumn{1}{|c|}{ Plurilingual and intercultural strategies } & \multicolumn{2}{c|}{ Attitude } \\
\hline & $\mathrm{M}$ & $\mathrm{SD}$ \\
\hline Éveil aux langues/translanguaging & 3.85 & .61 \\
\hline CLIL & 3.56 & .48 \\
\hline Intercultural Education & 3.35 & .48 \\
\hline Sporadic interventions & 3.22 & .56 \\
\hline
\end{tabular}

Before the ANOVA test was applied, normality and homogeneity of variance assumptions were tested, and the results proved they were sustained.

The ANOVA results (Tab. 11) revealed that the interaction between the plurilingual and intercultural strategies adopted by the schools and attitude was significant, $\mathrm{F}(3,633)$ $=21.58, \mathrm{p}<.001$. Post-hoc comparisons with the Bonferroni method indicated that students exposed to Éveil aux langues/translanguaging pedagogy have a significantly higher attitude compared with students attending schools which apply Intercultural education $(\mathrm{p}<.001)$ or only Sporadic intervention in the domain of plurilingual and intercultural education $(p<.001)$ and with students in the CLIL group $(p=.015)$. Students who have been exposed to CLIL have a significantly more positive attitude compared with students attending schools belonging to the Intercultural education group $(p=.002)$ and the Sporadic interventions group $(p<.001)$. We found a slightly significant difference between students in the Intercultural education group and in the Sporadic intervention group $(p=.045)$. Fig. 3 shows the box plot of data related to attitude across 'Plurilingual and intercultural strategies'. 
(C) Italiano LinguaDue 2. 2021. M. Bellinzona, V. Carbonara, Secondary students' attitudes towards linguistic diversity: an investigation on individual and educational aspects in Italian schools

Table 11. One-W ay ANOVA Summary Table for Plurilingual and Intercultural Strategies

\begin{tabular}{l|c|c|c|c|c}
\hline Source & SS & Df & MS & F & Sig. \\
\hline Between groups & 17.53 & 3 & 5.845 & $21.58^{*}$ & .000 \\
Within groups & 171.43 & 633 & .271 & & \\
\hline
\end{tabular}

Figure 3. Boxplot for Attitude across 'Plurilingual and intercultural strategies'

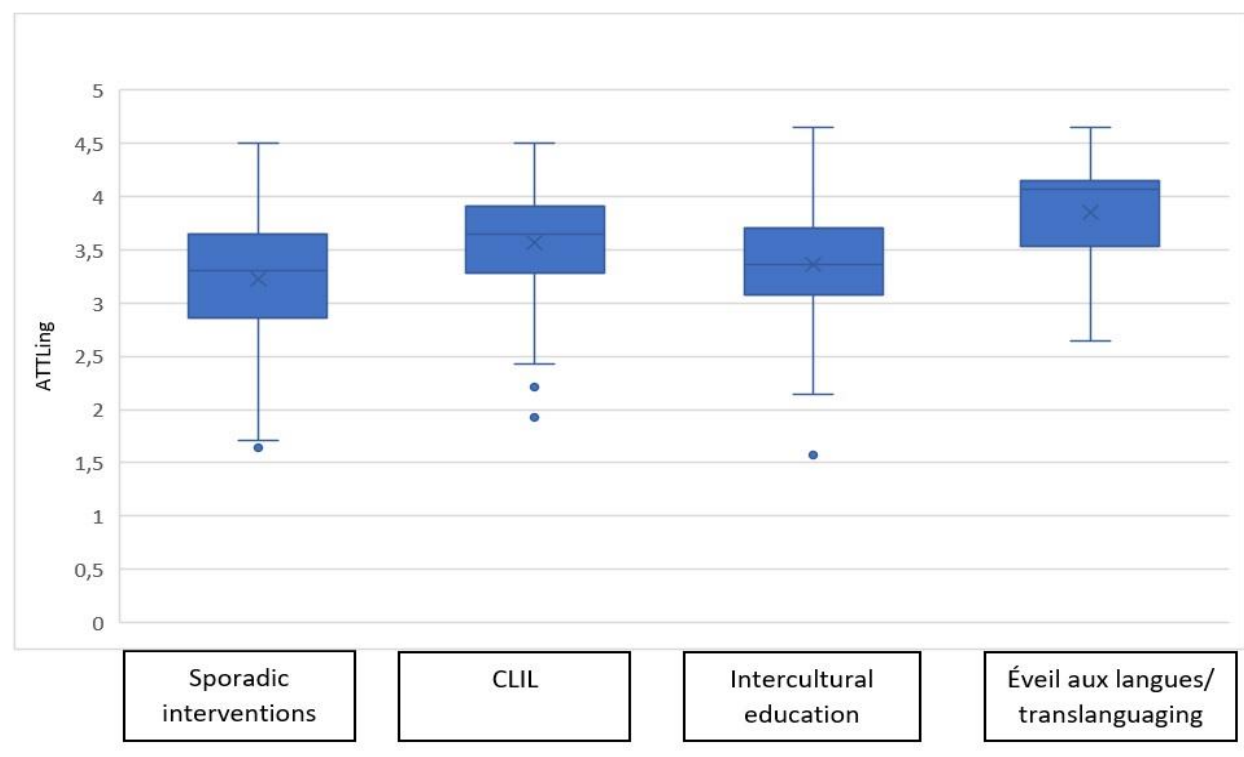

We conducted a second One-Way ANOVA in order to investigate whether the numbers of signs in the linguistic schoolscape could influence attitude towards linguistic diversity, since the mean difference between the groups 'less than 100', 'between 100 and 150 ' and 'more than 150' seems to support this hypothesis (Tab. 12). However, since some ANOVA assumptions have been violated, we decided to apply the rank-based nonparametric Kruskal-Wallis $\mathrm{H}$ Test. The test shows that there was a statistically significant difference in attitude score between the different groups, $\chi 2(2)=25.07, p<$ .001 , with a mean rank attitude score of 346.61 for the group 'More than 150 signs', 338.52 for the group 'Between 100 and 150 signs' and 264.89 for the group 'Less than 100 signs'. Post-Hoc pairwise comparisons with the Bonferroni method indicate that students attending schools with less than 100 signs in the linguistic schoolscape have a significant lower attitude towards linguistic diversity compared to the students whose educational environment displays between 100 and 150 and more than 150 signs $(\mathrm{p}<.001)$. No differences have been found between the two latter groups.

Table 12. Descriptive statistic for Attitude towards linguistic diversity according to number of signs displayed in the linguistic schoolscape

\begin{tabular}{l|c|c}
\hline Number of signs displayed in the linguistic schoolscape & \multicolumn{2}{|c}{ Attitude } \\
\hline & $\mathrm{M}$ & $\mathrm{SD}$ \\
More than 150 & 3.47 & .53 \\
Between 100 and 150 & 3.45 & .46 \\
Less than 100 & 3.20 & .58 \\
\hline
\end{tabular}


Successively, we conducted an Individual Sample T-Test aiming at examining the impact of pluralistic signs in the linguistic schoolscape on attitude. The results (Tab. 13) reveal that students attending schools with more than $10 \%$ of pluralistic signs displayed in the schoolscape have a statistically significantly higher attitude towards linguistic diversity compared to their peers attending schools with a lower percentage of pluralistic signs, $\mathrm{t}(635)=-5.45, \mathrm{p}<.001$.

Table 13. Independent-Samples T-Test Summary Table for Percentage of pluralistic signs in the linguistic schoolscape

\begin{tabular}{ccccccc}
\hline & \multicolumn{6}{c}{ Percentage of pluralistic signs in the linguistic schoolscape } \\
\cline { 2 - 7 } & \multicolumn{2}{c}{ Less than $10 \%$} & \multicolumn{4}{c}{ More than $10 \%$} \\
\\
\cline { 2 - 7 } Attitude & $\mathrm{M}$ & $\mathrm{SD}$ & $\mathrm{M}$ & $\mathrm{SD}$ & $\mathrm{T}$ & $\mathrm{df}$ \\
\cline { 2 - 7 } & 3.27 & .54 & 3.50 & .51 & $-5.45^{*}$ & 635 \\
\hline
\end{tabular}

Finally, we investigated whether the presence of students with an immigrant background at schools influenced students' attitude towards linguistic diversity (cf. Table 6). When we conducted a second Individual Sample T-Test, however, we could not find any significant difference between the students attending schools with more than $30 \%$ of students with an immigrant background and the students in schools with less than $30 \%$ of immigrant students $(\mathrm{p}=.057)$.

\section{DISCUSSION AND CONCLUSIONS}

In this paper, secondary students' attitudes towards linguistic diversity have been investigated in relation to different factors. To the best of our knowledge, it is one of the first attempts in Italy to explore students' attitudes that adopts a quantitative approach and includes a large number of participants representing different areas of the country. A specific research instrument, namely a questionnaire with both factual and attitudinal questions (Dörnyei, 2007), has been designed. This instrument takes into account not only the prominent research approaches to language attitudes (Sharp et al., 1973; Baker, 1992; Huguet, 2007 inter alia), but also the international literature on multilingualism, accepting the challenge of the 'multilingual turn' in applied linguistics (May, 2013). More recently, the debate over multilingualism has raised questions on how to incorporate a holistic view in data collection and analysis, moving away from the monolingual approach, which considers languages, and therefore language attitudes, as separate entities (Cenoz, 2009; Cummins, Early, 2011). While most of the studies focus on attitudes towards one or more specific languages, in this paper we frame language attitude as a complex construct, considering the whole linguistic ecology of the educational and societal contexts.

We are aware that attitudes change according to the specific language considered, as there is a strong association between languages and the corresponding linguistic communities, to the extent that the conceptualization of language attitude often includes attitudes towards the speakers. As stated by Sharp et al. (1973: 37), in fact, «attitude towards a language might arise from, or be influenced by, attitude towards the people who spoke that language». Nonetheless, we believe that attitude towards linguistic diversity is a concept which both includes and exceeds the idea of language attitude. The preferences that everyone has towards one or more languages do not compromise ideologies, beliefs and attitudes towards the whole of linguistic diversity. Moreover, this view of linguistic 
diversity, which is mirrored in the questionnaire contents, responds to EU language policy documents, envisioning a multilingual education as a mainstream approach (García, Li Wei, 2014).

The research gives a broad overview of Italian students' attitudes towards linguistic diversity, relying on a representative sample (No. 642) of secondary students, from different social, linguistic and educational contexts. This allowed us to answer the first research question. Preliminary results, in fact, show that secondary school students in Italy have, on average, a fairly strong attitude towards linguistic diversity (3.38 over 5 ). The outcome is consistent in the various areas investigated, that is, both in society and within the educational context. Regarding the latter case, the students mostly assigned high values on the Likert scale for items related to an enhancement of multilingualism at school and in the classroom. This is encouraging from a language policy prospective: for a top-down language policy to be efficient, it is necessary the support by those who are affected by the policy itself, in terms of language ideologies. Italian schools seem to be resourceful contexts in which a plurilingual education, as framed by the Council of Europe (2012) and in the international debate over the multilingual turn (May, 2013), can already find validation.

As mentioned, linguistic diversity within the wider society and ideologies on linguistic rights linked to the maintenance of the mother tongue, also find ample support within our sample. The descriptive analysis, therefore, offered a promising overview of the degree and type of attitudes towards linguistic diversity of secondary students in Italy. Nonetheless, the data relating to each school and some characteristics of the students showed a fluctuation in attitude. We have attempted to interpret this fluctuation based on the formulated research question, investigating the elements that we hypothesized could influence and predict it.

In terms of individual factors, our results partially confirm what previous research has already revealed (Wright, 1999). First, female students show a significantly more positive attitude than male. Gender, in a multiple regression, is the most predictive variable. Age also influences attitude: students attending lower secondary school, in fact, scored higher compared to their upper secondary peers. This is a relevant outcome in terms of educational practices which, from our perspective, should be seriously taken into consideration. Most of the projects related to plurilingual and intercultural education have been implemented in primary and lower secondary schools and are less common in upper secondary schools. This is often justified by the time needed to cover the entire national curriculum contents; however, the varying degrees of attitudes towards linguistic diversity should be an encouragement to continue planning specific interventions in this direction.

The exposure to different linguistic and cultural experiences, determined both by schools and personal circumstances, seems to have an impact on attitudes. On the one hand, we found a significant correlation between the number of languages in students' repertoire and attitude, which reveal the importance of developing and eventually maintaining plurilingual competences, including both those previously acquired by students and those matured at schools. On the other hand, students with an immigrant background were significantly more disposed to linguistic diversity than their native Italian peers. This overturned the widespread view related with this category of learners as deficient students and can be, or better should be, leveraged as a resource within the educational context (Cummins, Early, 2011).

Concerning the educational environment, we analysed whether the adoption of specific approaches or language strategies in class and in the management of the linguistic schoolscape affect students' attitudes towards linguistic diversity. Results showed that students attending S. 2, where 'éveil aux langue' and translanguaging pedagogy are widely applied, have a significantly more positive attitude compared to the rest of the sample. 
This outcome confirms and strengthens previous qualitative research (Candelier, 2003; Carbonara, Scibetta 2020b) regarding the effectiveness of these educational approaches.

To a lesser extent, students exposed to CLIL activities also exhibit a more positive attitude compared to their peers attending schools which promote mainly intercultural or sporadic interventions. The presence of CLIL programs, therefore, seems to enhance the development of positive attitudes both towards the single languages of the curriculum, as demonstrated by Lasagabaster and Sierra (2009), and towards linguistic diversity as a whole. We presume that this is due to the nature of 'éveil aux langue'/translanguaging and CLIL methods which focus on linguistic aspects in a productive manner, stimulating curiosity regarding language similarities and functioning as well as a concrete and enduring engagement of linguistic repertoires across the different learning activities.

Intercultural education seems to slightly significantly affect students' attitudes only compared with those exposed to sporadic interventions. This comforting result proves that when the students' reflection over diversity is enriched by educational activities always generates a positive impact. However, intercultural education, which in Italy is strongly established, seems to have a limited effect if compared with the other more linguistic oriented approaches. This may be because the schools applying intercultural education promote activities mainly centered on cultural aspects rather than linguistics. Considering that the questionnaire administered in this study included a section focussing on cultural attitude, further analysis is needed to verify the effect of intercultural education on other aspects related to students' attitudes.

The use of the schoolscape is also important in the development of students' attitudes. Our results, in fact, show that both the quantitative and qualitative characteristics of the schoolscape have an impact. Students from the schools which display a larger number of signs have a more positive conception of diversity, suggesting that a greater multimodal semiotic engagement also has a role in shaping students' openness. We would like to highlight that the schools with a bare schoolscape generally overlap with the ones where only sporadic interventions are pursued. This is not surprising, since several studies found that instructional strategies based on plurilingual and intercultural education exploit profoundly the linguistic schoolscape (Menken et al., 2018; Carbonara, Scibetta, 2020b). Moreover, an even larger impact is evidenced by the presence of pluralistic signs, which implies a meaningful enactment of plurilingual and intercultural ideologies. The importance of the educational aspects described above is also sustained by the fact that the sole presence of students from an immigrant background in class, without a purposefully engagement of linguistic plurality in instruction does not determine a higher attitude in students.

To conclude, even though it is clear that further detailed studies might be needed, our results disclosed relevant strengths and limitations of Italian language education in relation to the development of a positive mindset towards linguistic heterogeneity. These outcomes, in our opinion, should be acknowledged by stakeholders and educators involved in micro and macro language policy and planning. 
(C) Italiano LinguaDue 2. 2021. M. Bellinzona, V. Carbonara, Secondary students' attitudes towards linguistic diversity: an investigation on individual and educational aspects in Italian schools

\section{REFERENCES}

Albury N. (2020), "Language attitudes and ideologies on linguistic diversity", in Schalley A. C., Eisenchlas S. A. (eds.), Handbook of Home Language Maintenance and Development: Social and Affective Factors, De Gruyter Mouton, Boston, pp. 357-376: DOI https://doi.org/10.1515/9781501510175.

Bagna C. et al. (2018), "Le lingue dei cittadini stranieri", in ISTAT, Istituto Nazionale di Statistica (a cura di), Vita e percorsi di integrazione degli immigrati in Italia, pp. 219-247: https://www.istat.it/it/files//2019/05/Vita-e-percorsi.pdf.

Bagna C., Bellinzona M. (forthcoming), "Italian Linguistic Schoolscape: Neoplurilingualism in an Age of Migration", in Krompák E. et al. (eds.), Linguistic Landscape and Educational Spaces, Multilingual Matters, Clevedon.

Baker C. (1992), Attitudes and language, Multilingual Matters, Clevedon.

Bellinzona M. (2021), Linguistic landscape. Panorami urbani e scolastici nel XXI secolo, FrancoAngeli, Milano.

Brown J. D. (2001), Using surveys in language programs, Cambridge University Press, Cambridge.

Brown K. (2012), "The Linguistic Landscape of Educational Spaces: Language Revitalization and Schools in Southeastern Estonia", in Gorter D. et al. (eds.), Minority Languages in the Linguistic Landscape, Palgrave Macmillan, London, pp. 281298.

Burstall C. (1975), "French in the primary school: the British experiment", in Canadian Modern Language Review, 31, 5, pp. 388-402.

Candelier M. (2017), "Awakening to Languages and Educational Language Policy", in Cenoz J. et al. (eds.), Language Awareness and Multilingualism, Springer, Cham, pp. 161172.

Candelier M. (ed.) (2003), Evlang - l'éveil aux langues à l'école primaire, De Boek-Duculot, Bruxelles.

Carbonara V. (2017), "Contatto linguistico, percezione linguistica e pratiche didattiche nelle scuole secondarie di primo grado della provincia di Alessandria. Il caso di Serravalle Scrivia", in Vedovelli M. (ed.), L'italiano dei nuovi italiani, Atti del xix Convegno Nazionale del Giscel, Aracne, Roma, pp. 227-245.

Carbonara V., Scibetta A. (2020a), Imparare attraverso le lingue. Il translanguaging come pratica didattica, Carocci, Roma.

Carbonara V., Scibetta A. (2020b), "Integrating translanguaging pedagogy into Italian primary schools: implications for language practices and children's empowerment", in International Journal of Bilingual Education and Bilingualism, pp. 1-2, DOI https://doi.org/10.1080/13670050.2020.1742648.

Caruana S. (2007), "Language use and language attitudes in Malta", in Lasagabaster D., Huguet A. (eds.), Multilingualism in European bilingual contexts: Language use and attitudes, Multilingual Matters, Clevedon, pp. 184-207.

Cenoz J. (2001), "Three languages in contact: Language attitudes in the Basque Country", in Lasagabaster D., Sierra J. M. (eds.), Language Awareness in the Foreign Language Classroom, University of the Basque Country, Zarautz, pp. 37-60.

Cenoz J. (2009), Towards multilingual education: Basque educational research from an international perspective, Multilingual Matters, Clevedon.

Charmaz K. (2006), Constructing Grounded Theory: A practical guide through qualitative analysis, SAGE Publication, London.

Chini M., Andorno C. (2018), Repertori e usi linguistici nell'immigrazione. Una indagine su minori alloglotti dieci anni dopo, FrancoAngeli, Milano. 
(C) Italiano LinguaDue 2. 2021. M. Bellinzona, V. Carbonara, Secondary students' attitudes towards linguistic diversity: an investigation on individual and educational aspects in Italian schools

Clark J., Dervin F. (2014), Reflexivity in Language and Intercultural Education. Rethinking Multilingualism and Interculturality, Routledge, New York.

Cognigni E. (2020), Il plurilinguismo come risorsa. Prospettive teoriche, politiche educative e pratiche didattiche, Edizioni ETS, Pisa.

Cook V. (2006), 'Interlanguage, multi-competence and the problem of the 'second' language", in Rivista di Psicolinguistica Applicata, 6, pp. 39-52.

Council of Europe (2012), FREPA. A Framework of Reference for Pluralistic Approaches to Languages and Cultures: https://www.ecml.at/Portals/1/documents/ECMLresources / CARAP-EN.pdf?ver=2018-03-20-120658-443.

Creswell J. W. (2008), Educational research: Planning, conducting, and evaluating quantitative and qualitative approaches to research, 3rd ed., Merrill-Pearson Education, Upper Saddle River.

Creswell J. W. et al. (2003), "Advanced mixed methods research designs", in Tashakkori A., Teddlie C. (eds.), Handbook on mixed methods in the behavioral and social sciences, Sage Publications, Thousand Oaks, pp. 209-240.

Cummins J., Early M. (2011), Identity Texts the Collaborative Creation of Power in Multilingual Schools, Trentham Books, London.

De Angelis G. (2011), “Teachers' beliefs about the role of prior language knowledge in learning and how these influence teaching practices", in International Journal of Multilingualism, 8, 3, pp. 216-234:

DOI https://doi.org/10.1080/14790718.2011.560669.

De Pascale S., Marzo S. (2016), "Gli italiani regionali. Atteggiamenti linguistici verso le varietà geografiche dell’italiano", in Incontri: Rivista Europea di Studi Italiani, 31, 1, pp. 61-76: DOI http://doi.org/10.18352/incontri.10151.

Demetrio D., Favaro G. (2002), Didattica interculturale, FrancoAngeli, Milano.

Dervin F. (2012), "Cultural Identity, Representation and Othering", in Jackson J. (ed), The Routledge Handbook of Language and Intercultural Communication, Routledge, Abingdon, pp. 181-194.

Dewaele J. M. (2010), Emotions in multiple languages, Palgrave Macmillan, Basingstoke.

Dörnyei Z. (2003), Questionnaires in second language research: Construction, administration, and processing, Lawrence Erlbaum Associates, London.

Dörnyei Z. (2007), Research methods in applied linguistics, Oxford University Press, Oxford.

Dörnyei Z., Csizér K. (2002), "Some dynamics of language attitudes and motivation: Results of a longitudinal nationwide survey", in Applied linguistics, 23, 4, pp. 421-462: DOI https://doi.org/10.1093/applin/23.4.421.

Duarte J., Günther-van der Meij M. (2018), "A Holistic Model for Multilingualism in Education", in E-Journ ALL, Euro American Journal of Applied Linguistics and Languages, 5, 2, pp. 24-43:

http://www.e-journall.org/wp-content/uploads/Duarte_Guenther_5.2.pdf.

Edwards J. (2004), "Bilingualism: Contexts, constraints, and identities" in Journal of Language and Social Psychology, 23, 1, pp. 135-141:

DOI https://doi.org/10.1177/0261927X03260811.

Ellard J. H., Rogers T. B. (1993), "Teaching questionnaire construction effectively: The Ten Commandments of question writing", in Contemporary Social Psychology, 17, pp. 17-20.

Etxeberria F. et al. (2002), "Percepción y autovaloración de la adquisición bilingüe en los sujetos de segundo ciclo de ESO (Ensenanza Secundaria Obligatoria): Primeros resultados", paper presented at the Second International Symposium on Bilingualism (Vigo, October 23-26, 2002), University of Vigo, Vigo. 
(C) Italiano LinguaDue 2. 2021. M. Bellinzona, V. Carbonara, Secondary students' attitudes towards linguistic diversity: an investigation on individual and educational aspects in Italian schools

European Commission (2020), Education begins with language. Thematic report from a programme of seminars with peer learning to support the implementation of the Council Recommendation on a comprehensive approach to the teaching and learning of languages (2019-2020):

https://op.europa.eu/en/publication-detail/-/publication/6b7e2851-b5fb-11eabb7a-01aa75ed71a1/language-en.

Field A. (2009), Discovering Statistics Using SPSS, Sage Publications, Thousand Oaks.

García O. et al. (2017), The Translanguaging Classroom: Leveraging Student Bilingualism for Learning, Caslon, Philadelphia.

García O., Li Wei (2014), Translanguaging: Language, Bilingualism and Education, Palgrave Macmillan, Basingstoke.

García O., Kleyn T. (eds.) (2016), Translanguaging with Multilingual Students: Learning from Classroom Moments, Routledge, New York.

García O., Otheguy R. (2021), "Conceptualizing Translanguaging Theory/Practice Juntos Translanguaging and Transformative Teaching for Emergent Bilingual Students", City University of New York - New York State Initiative on Emergent Bilinguals (ed.), Lessons from the CUNY-NYSIEB Project, Routledge, New York, pp. 280-283.

Gardner R. C. (1985), Social psychology and second language learning: The role of attitudes and motivation, Edward Arnold, London.

Garrett P. (2010), Attitudes to language, Cambridge University Press, Cambridge.

Gawronski B. (2007), "Editorial: Attitudes can be measured! But what is an attitude?", in Social Cognition, 25, 5, pp. 573-581.

Gorter D. Arocena E. (2020), “Teachers' beliefs about multilingualism in a course on translanguaging", in System, 92:

DOI https://doi.org/10.1016/j.system.2020.102272.

Guerini F. (2009), "Repertori complessi e atteggiamenti linguistici: gli immigrati di origine ghanese in provincia di Bergamo", in Studi Italiani di Linguistica Teorica e Applicata, XXXVIII, 1, pp. 73-88.

Haukås Å. (2016), “Teachers' beliefs about multilingualism and a multilingual pedagogical approach" [online], in International Journal of Multilingualism, 13, 1, pp. 1-18: https://www.researchgate.net/publication/279251445_Teachers'_beliefs_about_ multilingualism_and_a_multilingual_pedagogical_approach.

Huck S. W. (2012), Reading statistic and Research, 6th ed., Pearson, Boston.

Huguet A. (2007), "Language use and language attitudes in Catalonia", in Lasagabaster D., Huguet A. (eds.), Multilingualism in European bilingual contexts: Language use and attitudes, Multilingual Matters, Clevedon, pp. 17-39.

Huguet A., Janés J. (2008), "Mother Tongue as a Determining Variable in Language Attitudes. The Case of Immigrant Latin American Students in Spain", in Language and Intercultural Communication, 8, 4, pp. 246-260.

Ianos M.A. et al. (2017), "Can language attitudes be improved? A longitudinal study of immigrant students in Catalonia (Spain)", in International Journal of Bilingual Education and Bilingualism, 20, 3, pp. 331-345.

ISMU, Iniziative e Studi sulla Multietnicità (2021), Plurilinguismo nella scuola che (s)cambia. Esperienze e pratiche didattiche per l'educazione linguistica:

https://www.ismu.org/plurilinguismo-nella-scuola-che-scambia/.

ISTAT, Istituto Nazionale di Statistica (2020), Identità e percorsi di integraz̧ione delle seconde generazioni in Italia:

https://www.istat.it/it/files/2020/04/Identit\%C3\%A0-e-percorsi.pdf.

Lambert W. E. et al. (1960), "Evaluational reactions to spoken languages", in Journal of Abnormal and Social Psychology, 60, 1, pp. 44-51.

Lasagabaster D. (2015), "Different Educational Approaches to Bi- or Multilingualism and Their Effect on Language Attitudes", in Juan-Garau M., Salazar-Noguera J. (eds.), 
(C) Italiano LinguaDue 2. 2021. M. Bellinzona, V. Carbonara, Secondary students' attitudes towards linguistic diversity: an investigation on individual and educational aspects in Italian schools

Content-based Language Learning in Multilingual Educational Environments, Springer, Cham, pp. 13-30.

Lasagabaster D., Sierra J. M. (2009), "Language attitudes in CLIL and traditional EFL classes", in International CLIL research journal, 1, 2, pp. 4-17.

Little D., Kirwin D. (2019), Engaging with Linguistic Diversity. A Study of Educational Inclusion in an Irish Primary School, Bloomsbury Academic, London.

May S. (2013), "Introducing the 'Multilingual Turn"', in May S. (ed.), The Multilingual Turn Implications for SLA, TESOL, and Bilingual Education, Routledge, New York, pp. 116.

Mayring P. (2004), "Qualitative content analysis", in A companion to qualitative research, 1, 2, pp. 159-176.

Menken K. et al. (2018), "Increasing Multilingualism in Schoolscapes", in Linguistic Landscape, 4, 2, pp. 101-27.

MIUR, Ministero dell'Istruzione, dell'Università e della Ricerca (2018), Indicażioni nażionali e nuovi scenari:

https://www.miur.gov.it/documents/20182/0/Indicazioni+nazionali+e+nuovi+ scenari/3234ab16-1f1d-4f34-99a3-319d892a40f2.

MIUR, Ministero dell'Istruzione, dell'Università e della Ricerca (2014), Linee guida per l'accoglienza e l'integrazione degli alunni stranieri:

https://www.istruzione.it/allegati/2014/linee_guida_integrazione_alunni_stranier i.pdf.

MIUR, Ministero dell'Istruzione, dell'Università e della Ricerca (2020), Gli alunni con cittadinanza non italiana. A.S. 2018/2019:

https://www.miur.gov.it/documents/20182/2447435/Notiziario+Alunni+con+ Cittadinanza+non+italiana+A.S.+2018_2019.pdf/ad84f9fc-efe5-46bd-2aa4091b81727197?version $=1.0 \& \mathrm{t}=1593701066178$.

Oppenheim A.N. (1992), Questionnaire design, interviewing and attitude measurement, Pinter Publishers, New York.

O'Rourke B. (2011), "Whose language is it? Struggles for language ownership in an Irish language classroom", in Journal of Language, Identity \& Education, 10, 5, pp. 327-345.

Pajares M. F. (1992), "Teachers' Beliefs and Educational Research: Cleaning Up a Messy Construct", in Review of educational research, 62, 3, pp. 307-332: http://emilkirkegaard.dk/da/wp-content/uploads/Teachers-Beliefs-and-

Educational-Research-Cleaning-Up-a-Messy-Construct.pdf.

Sarnoff I. (1970), "Social attitudes and the resolution of motivational conflict", in Jahoda, M., Warren N. (eds.), Attitudes, Penguin, Harmondsworth, pp. 279-284.

Schwarz N. (2007), "Attitude construction: evaluation in context", in Social Cognition, 25, 5, pp. 638-656.

Septién Ortiz J. M. (2006), Una escuela sin fronteras. La enseñanza del alumnado inmigrante en Alava, Ararteko, Vitoria-Gasteiz.

Sharp D. et al. (1973), Attitudes to Welsh and English in the Schools of Wales, Macmillan Education, London.

Siebetcheu R. (2018), "La scuola del nuovo millennio: tra italiano, dialetti e altre lingue", in Coonan C. M. et al. (a cura di), La didattica delle lingue nel nuovo millennio. Le sfide dell'internazionalizzazione, Edizioni Ca' Foscari, Venezia, pp. 117-134.

Sordella S. (2015), "L'educazione plurilingue e gli atteggiamenti degli insegnanti", in Italiano LinguaDue, 7, 1, pp. 60-110: https://riviste.unimi.it/index.php/promoitals/article/view/5038.

Sordella S., Andorno C. (2017), "Esplorare le lingue in classe. Strumenti e risorse per un laboratorio di éveil aux langues nella scuola primaria”, in Italiano LinguaDue, 9, 2, pp. 162-228: https://riviste.unimi.it/index.php/promoitals/article/view/9875. 
(C) Italiano LinguaDue 2. 2021. M. Bellinzona, V. Carbonara, Secondary students' attitudes towards linguistic diversity: an investigation on individual and educational aspects in Italian schools

Spolsky B. (2004), Language policy, Cambridge University Press, Cambrige.

Stake R. (2005), "Qualitative case studies", in Denzin N. K., Lincoln Y. S. (eds.), The Sage handbook of qualitative research, Sage Publications, Thousand Oaks, pp. 443-466.

Szabó T. P. (2015), "The management of diversity in schoolscapes: an analysis of Hungarian practices", in Apples: Journal of Applied Language Studies, 9, 1, pp. 23-51.

Visser, P. S., Mirabile, R. R. (2004), "Attitudes in the social context: the impact of social network composition on individual-level attitude strength", in Journal of personality and social psychology, 87, 6, pp. 779-795.

Wright M. (1999), "Influences on learner attitudes towards foreign language and culture", in Educational Research, 41, 2, pp. 197-208. 